\title{
1 Investigation of ship cooling system operation for improving energy efficiency
}

\section{Gerasimos Theotokatos $^{{ }^{*}}$, Konstantinos Sfakianakis ${ }^{2}$ and Dracos Vassalos ${ }^{1}$}

1. Department of Naval Architecture, Ocean and Marine Engineering, University of Strathclyde, G4 0LZ, Glasgow, UK

2. Department of Electronic and Electrical Engineering, University of Strathclyde, G1 1XW, Glasgow, UK

* Corresponding author: Tel.: +44(0)1415483462 e-mail address: gerasimos.theotokatos@strath.ac.uk

\begin{abstract}
The application of recently introduced IMO regulations for reduction of $\mathrm{CO}_{2}$ gaseous emissions as well as the initiatives for greener shipping, rendered the efforts for improving on-board energy systems performance to be of high priority. This study focuses on the investigation of the on-board operation of the combined sea/fresh water cooling system of a merchant ship. The detailed model of a cooling system is presented based on energy and mass conservation laws. The simulation input data includes the system geometry and arrangement, the operational characteristics of cooling pumps, the control scenarios for the system valves as well as data for calculating the pipes friction and minor losses coefficients, wherefrom the system performance parameters can be calculated. The cooling system energy consumption was estimated considering a typical annual ship operational profile. Two cases were investigated; first, a conventional case of controlling the sea water and fresh water temperatures by using three-way valves and, second, a more sophisticated case of installing variable speed motors for driving the system pumps. The obtained results are compared in terms of annual power consumption leading to conclusions about the system performance. The developed models can be used as an assessment tool for improving shipboard power demand early in the design stage and, also, during operation.
\end{abstract}

Keywords: Ship piping systems; cooling system, modelling; ship energy efficiency; variable speed pump operation. 


\section{Introduction}

The last decade, ships energy efficiency and environmental performance have been of highest importance in shipping industry due to the fuel oil prices increase and the stringent emissions legislation concerning greenhouse gas emissions [1]. In this respect, the shipping industry has intensified its efforts for reducing ships energy consumption and gas emissions. Inevitably, the area of interest for many research groups and industry is focused on the performance improvement of the major on-board energy consumers, i.e. propulsion plants, hull/propeller etc. However, the ship auxiliary systems have not been attracted much attention, since their contribution to the total energy consumption is substantially lower than the respective one of the ship propulsion system.

The majority of the ship electrical energy utilisers include pumps, compressors and fans/blowers. Since the ship cooling systems usually comprise the largest ship pumps and operate for the majority of the ship lifetime, they are considered of vital importance in terms of improving the ship energy efficiency. Presently, the standard design methods for the cooling systems are based on considering the worst case scenarios e.g. tropical conditions and all the ship engines/machinery operating at their maximum load. As a consequence, the installed on-board systems are oversized and in turn, they demand a significantly greater amount of energy. Therefore, there is enough space for energy efficiency improvement at the design stage as well as during operation considering the introduction of new available technologies, such as variable frequency drives [2].

The typical pumps that are used by the shipping industry work at a constant speed under the rated (nominal) frequency (usually $60 \mathrm{~Hz}$ ) without taking into consideration the real system thermal power needs. In addition, the on-board system fluid flow control is performed with the use of bypass branches and/or throttling valves [2]. It is inevitable that the commonly used techniques end up to the system inefficient operation and therefore, energy saving technologies can be utilized as potential solutions [2-3]. In this respect, the pump motor speed control using Variable Frequency Drives (VFD) might be an effective solution that has not been adapted yet to a great extent in the shipping industry [4]. The energy saving is based on the concept of reducing the system operating pumps speed, and therefore, lowering the required power demand for the cases where the system operates in lower heat capacity conditions, which can be accommodated by reducing the cooling water flow rate.

Despite the importance of the applying energy saving technologies in ship systems, only limited published works have been found dealing with modelling, control and energy savings for the ship cooling system. In [5], a model capable of predicting the transient response of a merchant ship cooling system was developed and verified against measured data. Subsequently, it was used for investigating the influence of the controller parameters on the system behaviour. In [6], a similar methodology was followed to develop an appropriate linearised model capable of predicting the transient 
response of a containership cooling system. Based on this, two different control designs were investigated under various operating conditions for controlling the sea water and fresh water temperature. In [3], the energy savings that can be achieved by using a VFD on the cooling system pumps of two different ships were investigated considering fixed thermal energy demand and varying sea water temperature for the ship voyages throughout the period of one year. In this respect, further studies on the integrated sea water-fresh water cooling system investigation that consider the varying operating conditions and actual ship engines operating profiles are quite useful for providing insight to the overall system operation and the expected benefits for applying energy saving techniques.

The aim of this study is to realistically estimate the annual energy consumption of the integrated sea water/fresh water cooling system of a typical handymax bulk carrier for two different operation methods, namely constant speed and variable speed pump operation. The system was modelled by applying the energy and mass conservation equations in its components, whereas a typical annual operating profile was considered for the ship main and auxiliary engines. The model results, which include the head, volumetric flow rate and temperature of all system braches, as well as the pumps required power, were analysed and the ship annual energy saving potential was discussed.

\section{System Description}

Typical ship cooling water systems consist of three parts: the sea water (SW) cooling system, the low temperature (LT) fresh water cooling system and the high temperature (HT) fresh water cooling system, as shown in Figure 1. Since the seawater causes corrosion issues, fresh water is used for cooling the ship main and auxiliary machinery. Thus, one or more central coolers are installed on-board for cooling the hot fresh water exiting the ship machinery and heat exchangers by using sea water.

The seawater system comprises a number of water pumps connected in parallel. Usually two main pumps (one operating and one standby) and one smaller pump for operation at harbour are required; however three same main pumps could also be used provided that the two pumps have to supply the cooling water flow rate required to cover the design point operation (maximum flow rate scenario) [7]. The pumps function is to provide sea water to the central cooler(s) in order to remove the required heat from the fresh water. The sea water system pumps have to maintain the required flow rate and to provide the pressure increase required for covering the system pressure losses (induced to the system pipe lines, fittings and components) and the elevation of sea water. For the case where the pump operates at constant speed, the sea water flow rate is almost constant (although it depends on the system valves settings and the components fouling/corrosion condition), and therefore the temperature of the sea water exiting the central cooler varies with the cooler heat capacity, which depends on the serviced systems operating conditions. For the case where variable 
pump speed is used, the pump speed can be adjusted, so that the sea water flow matches the actual central cooler heat capacity and thus, the temperature of the sea water exiting the central cooler can be kept constant.

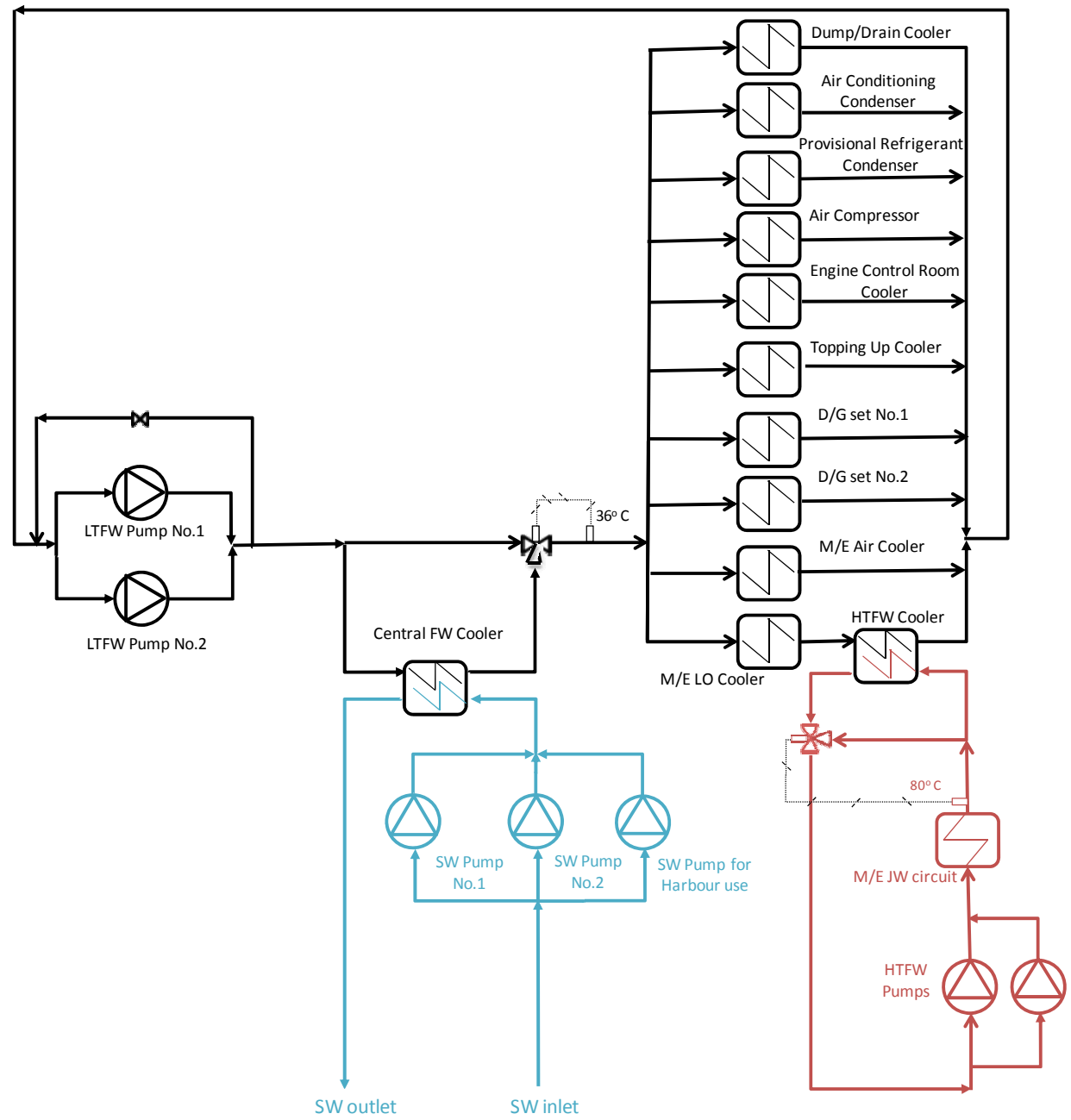

Figure 1: Bulk carrier integrated sea water/fresh water cooling water system diagram

The LT fresh water cooling system employs two (three in some cases) pumps [7] to service the main engine (M/E) (scavenging air cooler, lubricating oil cooler and HT fresh water cooler) and the auxiliary machinery components (Diesel-Electric generator (D/G) sets, air compressor, topping up cooler, dump drain cooler etc.). The temperature of the fresh water entering the system coolers is controlled by a three-way valve, which is continuously adjusted to maintain the temperature level at $36^{\circ} \mathrm{C}$. When the system operating conditions differ from the system design point (less heat has to be removed), the three-way valve mixes a flow at a lower temperature exiting from central cooler and a hotter by-pass flow (returning from system coolers and components). That is required since the low temperature fresh water pumps operate in constant speed and therefore, their flow rate does not depend on the serviced machinery instantaneous heat capacity. On the other hand, in the case of the variable pump speed, the flow rate can match the actual needs of the system and therefore, the three-way valve can remain in a position where the by-pass flow is zero.

The HT fresh water cooling system uses two pumps connected in parallel (one operates whilst the other remains standby) 
to provide water for cooling the engine metallic parts (jacket cooling water circuit). For the pump constant speed operation, the temperature of the water exiting the engine is indirectly adjusted to around $80^{\circ} \mathrm{C}$ (as proposed by the engine manufacturer, although this depends on the engine settings) by using a three-way valve that mixes a water flow at lower temperature exiting the HT fresh water cooler and the hot water flow exiting the engine. This is not required for the case of variable speed pump, where the pump speed is adjusted, so that the water flow exiting the engine is kept at the required temperature of $80^{\circ} \mathrm{C}$.

\section{System modelling}

In this work, the steady state operation of the integrated system of sea water/fresh water cooling system that is shown in Figure 2 was modelled. The governing equations were derived by applying the continuity equation in the system nodes, the extended Bernoulli equation in the system branches and the energy conservation equation in the system heat exchangers/coolers.

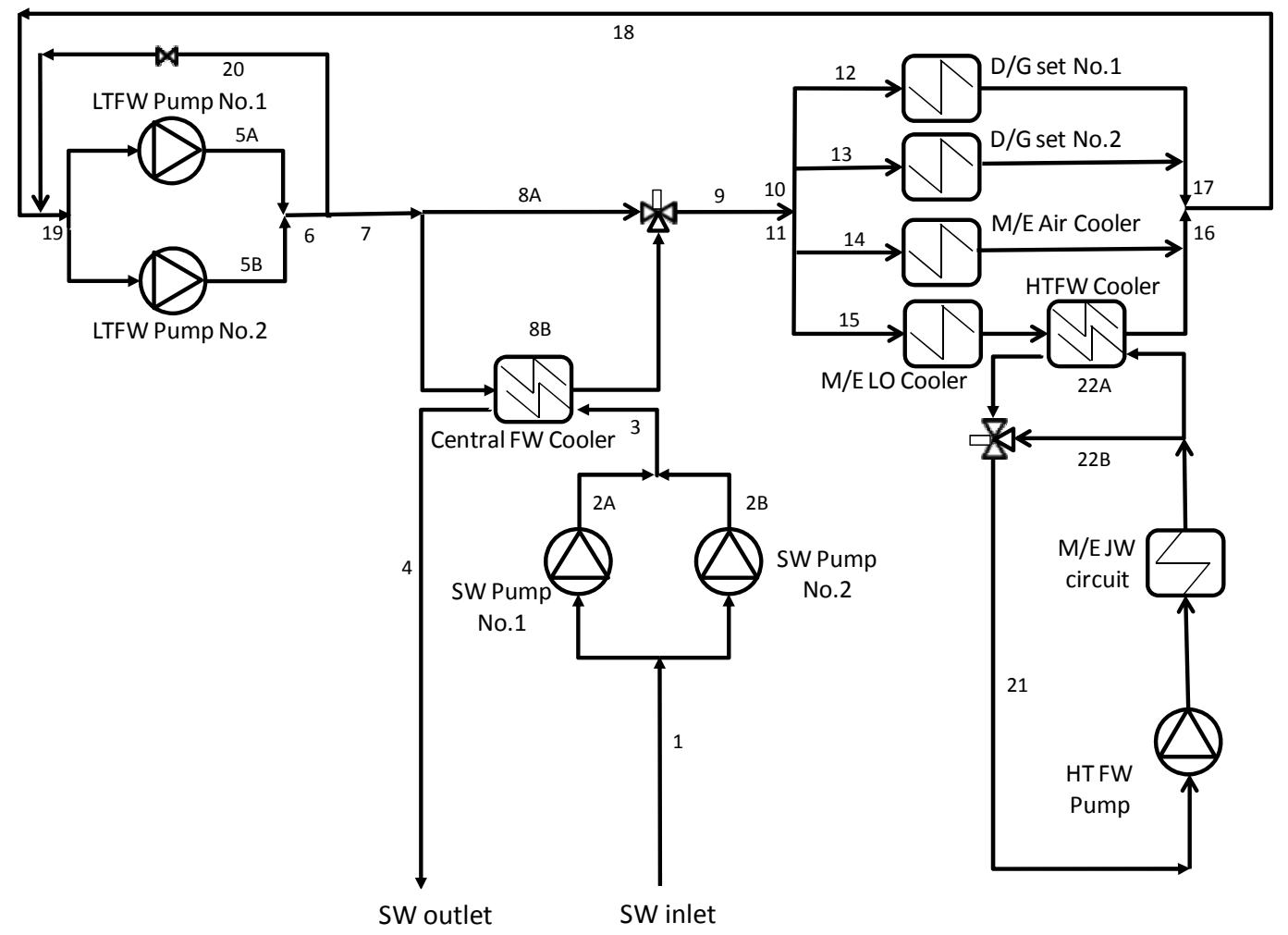

Figure 2: Modelled cooling water system layout

115 The head loss (in meters) of the system branches is calculated by taking into account the friction loss and the fittings 116 loss (valves, elbows, etc.) according to the following equation:

$$
\Delta h_{\text {loss }, i}=\left(f_{i} \frac{L_{i}}{D_{i}}+\Sigma K_{i}\right) \frac{\dot{V}_{i}^{2}}{2 g A_{i}{ }^{2}}
$$


where $\mathrm{i}$ denotes the $\mathrm{i}^{\text {th }}$ branch, $f$ is the friction factor, $L$ is the pipe length, $D$ is the pipe hydraulic diameter, $\Sigma K$ is the sum of loss coefficients of the fittings along the considered branch, $g$ is the gravitational acceleration, $\dot{V}$ is the volumetric flow rate and $A$ is the pipe internal cross-section area.

The friction factor is a function of Reynolds number for the laminar flow mode, whilst it can be calculated as a function of Reynolds number and the relative roughness for the turbulent flow mode by using various equations of implicit or explicit form. In this work, the Haaland equation [8] was used for calculating the friction factor as it has low computational cost and adequate accuracy exhibiting a maximum error of $1.4 \%$ according to [9]:

$$
f^{-0.5}=-1.8 \log _{10}\left[\left(\frac{e / D}{3.7}\right)^{1.11}+\frac{6.9}{R e}\right]
$$

where e/D denotes the relative roughness and $R e$ is Reynolds number.

The head loss of each cooler is calculated by using the following equation:

$$
\Delta h_{H E, \mathrm{j}}=K_{H E, \mathrm{j}} \dot{V}_{j}^{2}
$$

where $\mathrm{j}$ denotes the $\mathrm{j}^{\text {th }}$ heat exchanger, $K_{H E}$ is the heat exchanger loss coefficient and $\dot{V}$ is the volumetric flow rate.

The heat exchanger loss coefficient can be calculated based on the heat exchangers manufacturers' data or the methods reported in [10]. Typical values for the maximum (permitted) pressure drop lay in the range from 0.7 to 1 bar at the nominal flow point $[10-11]$.

The head increase of each pump (in meters) is usually expressed in the form of the pump characteristic curves, in which the pump head is plotted against the volumetric flow rate. For the case of centrifugal pumps, a second order polynomial equation can represent the pump characteristic curve. Thus, the pump head is calculated according to the following equation:

$$
\Delta h_{p, i}=a \dot{V}_{i}^{2}+b \dot{V}_{i}+c
$$

138 where $\mathrm{i}$ denotes the $\mathrm{i}^{\text {th }}$ pump, $\dot{V}$ is the pump volumetric flow rate and a, b, c are constants.

For each heat exchanger, the energy conservation provides the following equation:

$$
\dot{Q}_{H E}=\left.\dot{V} \rho c_{p}\left(T_{o}-T_{\text {in }}\right)\right|_{\text {cold }}=\left.\dot{V} \rho c_{p}\left(T_{\text {in }}-T_{o}\right)\right|_{\text {hot }}
$$

where $\dot{Q}_{H E}$ is the heat transferred from the hot fluid to the cold fluid, $\rho$ is the fluid density, $\mathrm{c}_{\mathrm{p}}$ is the fluid specific heat at constant pressure, $T_{\text {in }}$ is the fluid inlet temperature and $T_{\text {out }}$ is the fluid outlet temperature. equations:

$$
\dot{Q}_{C C}=\sum \dot{Q}_{L T, i}, \dot{Q}_{H T F W}=\dot{Q}_{M E, J W}
$$


where $\mathrm{i}$ denotes the $\mathrm{i}^{\text {th }}$ heat exchanger of the LT cooling system, $\dot{Q}_{C C}$ is the central cooler heat capacity, $\dot{Q}_{L T, i}$ is the heat capacity of $\mathrm{i}^{\text {th }}$ heat exchanger of LT cooling system, $\dot{Q}_{H T F W}$ is the HTFW cooler heat capacity and $\dot{Q}_{M E, J W}$ is the M/E jacket water circuit heat capacity.

The extended Bernoulli equation applied to the system branches provides the formulas given below.

$\underline{\text { Sea Water cooling system }}$

$$
\Delta h_{p, 2 A}-\Delta z-\sum_{i=1 \div 4} \Delta h_{\mathrm{loss}, \mathrm{i}}-K_{C C} \dot{V}_{3}^{2}=0
$$

When the LT fresh water pumps operate simultaneously the following equation has to be additionally taken into account:

$$
\Delta h_{p, 2 A}-\Delta h_{\mathrm{loss}, 2 \mathrm{~A}}-\Delta h_{p, 2 B}+\Delta h_{\mathrm{loss}, 2 \mathrm{~B}}=0
$$

\section{Low Temperature fresh water cooling system}

$$
\begin{aligned}
& \Delta h_{p, 5 A}-\sum_{\substack{i=5 A, 6-7,8 A, 9-10, 12,17-19}} \Delta h_{\mathrm{loss}, \mathrm{i}}-K_{H E, 12} \dot{V}_{12}^{2}=0 \\
& \Delta h_{\mathrm{loss}, 12}+K_{H E, 12} \dot{V}_{12}{ }^{2}-\Delta h_{\mathrm{los}, 13}-K_{H E, 13} \dot{V}_{13}{ }^{2}=0 \\
& \Delta h_{\mathrm{loss}, 10}+\Delta h_{\mathrm{loss}, 12}+K_{H E, 12} \dot{V}_{12}^{2}+\Delta h_{\mathrm{loss}, 17} \\
& -\Delta h_{\text {loss }, 11}-\Delta h_{\text {loss }, 14}-K_{H E, 14} \dot{V}_{14}{ }^{2}-\Delta h_{\text {loss }, 16}=0 \\
& \Delta h_{\mathrm{loss}, 14}+K_{H E, 14} \dot{V}_{14}^{2}-\Delta h_{\mathrm{loss}, 15} \\
& -\left(K_{H E, 15}+K_{H T F W}\right) \dot{V}_{15}^{2}=0 \\
& \Delta h_{\text {loss }, 8 \mathrm{~A}}-\Delta h_{\text {loss }, 8 B}=0 \\
& \Delta h_{\text {loss }, 19}+\Delta h_{\text {loss }, 5 \mathrm{~A}}+\Delta h_{\text {loss }, 16}-\Delta h_{\text {loss }, 20}=0 \\
& \Delta h_{p, 5 A}-\Delta h_{\mathrm{loss}, 5 \mathrm{~A}}-\Delta h_{p, 5 B}+\Delta h_{\mathrm{loss}, 5 \mathrm{~B}}=0
\end{aligned}
$$

\section{High Temperature fresh water cooling system}

$$
\Delta h_{p, 21}-\sum_{i=21,22 A} \Delta h_{\text {loss }, \mathrm{i}}-K_{H T F W} \dot{V}_{22 A}{ }^{2}-K_{M E, J W} \dot{V}_{21}^{2}=0
$$

$$
\Delta h_{\text {loss }, 22 \mathrm{~A}}-\Delta h_{\text {loss }, 22 B}=0
$$

The continuity equation applied in each system node and considering incompressible flow gives the following equations:

$$
\sum \dot{V}_{i}=0
$$

In the nodes where mixing of two flows occurs, the energy conservation provides the following equation:

$$
\dot{V}_{i n, 1} \rho_{i n, 1} c_{p, i n, 1} T_{i n, 1}+\dot{V}_{i n, 2} \rho_{i n, 2} c_{p, \text { in, } 2} T_{i n, 2}=\dot{V}_{o} \rho_{o} c_{p, o} T_{\mathrm{o}}
$$

\section{$\underline{\text { Pumps power calculation }}$}


The electric power that is needed for the pumps operation is calculated according to the following equation [12]:

$$
P_{e l, i}=\rho g \dot{V}_{p, i} \Delta h_{p, i} / \eta_{i}
$$

where $i$ denotes the $i^{\text {th }}$ pump, $\eta$ is the pump assembly efficiency that includes the pump, the motor and the variable speed drive efficiencies, i.e.:

$$
\eta_{i}=\eta_{p, i} \eta_{m} \eta_{d}
$$

The motor and drive efficiencies can be estimated according to the data provided in [13]. The considered variable speed drive efficiency as a function of its load percentage is shown in Figure 3. The maximum pump efficiency was estimated based on the volumetric flow rate and specific speed [12]. Then, the pump efficiency as function of its volumetric flow rate was estimated using the maximum pump efficiency, the specific speed and the normalised diagrams provided in [14]. In order to estimate the pump characteristic at a speed value different that the pump rated speed, the affinity laws were used [15]. According to them, similar operating points will exhibit the same efficiency and the volumetric flow rate, head and speed are related using the following equations:

$$
\dot{V}_{1} / \dot{V}_{2}=N_{1} / N_{2}, \quad h_{1} / h_{2}=\left(N_{1} / N_{2}\right)^{2}
$$

where 1 and 2 denote two similar points at pump speed $\mathrm{N}_{1}$ and $\mathrm{N}_{2}$, respectively.

Since the maximum pump efficiency is reduced at speed values different from the rated speed, the correction factor shown in Figure 4 was applied for calculating the maximum pump efficiency [14].

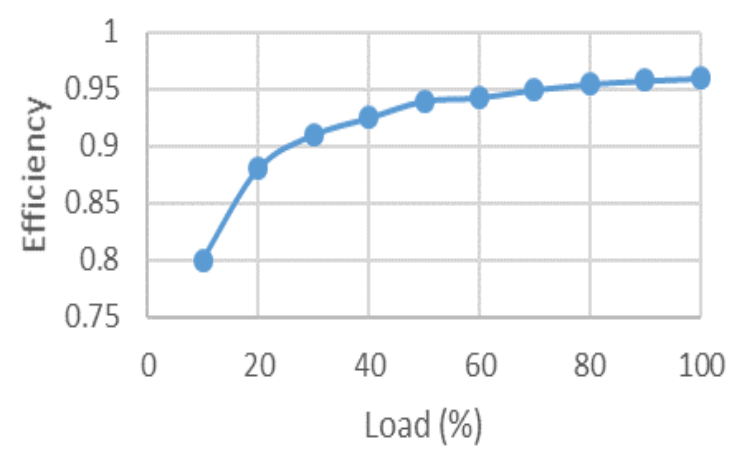

Figure 3: Variable speed drive efficiency as function of its load percentage

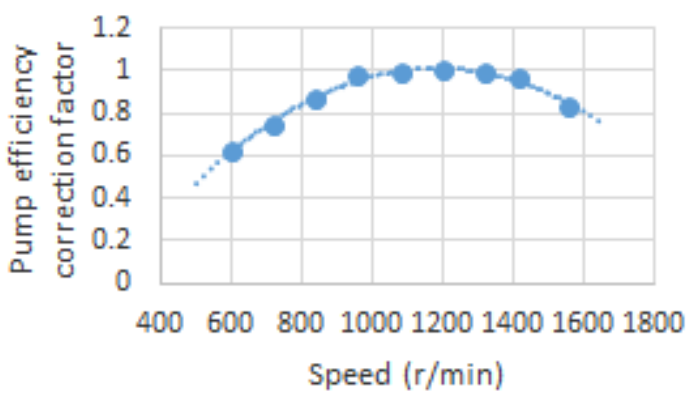

Figure 4: Pump efficiency correction factor 
The equations (1)-(22) were simultaneously solved in MATLAB computational environment by using the "fsolve"

193 function. For all the system coolers, the constraint that the terminals temperature difference has to be kept greater that

$194 \quad 5^{\circ} \mathrm{C}$ as proposed in [16] was taken into account.

195 The developed algorithm inputs include:

- Volumetric flow rate, head and speed at the pumps design operating points.

- Heat capacity of the system consumers (heat exchangers/main engine jacket cooling water circuit).

- Head loss coefficients for heat exchangers.

- Internal or hydraulic diameter of the pipes.

- Branches length.

- Number and type of fittings at each branch.

- Temperature set points for the system three way valves.

- Sea water temperature.

- Properties of the working fluid.

- Sea water elevation.

- Motors and variable speed drive efficiencies.

- Pumps operating speed.

The systems outputs include:

- The volumetric flow rate at each branch.

- The water temperature at each branch.

- The operating points (volumetric flow rate, head and efficiency) of each operating pump.

- The required electric power of each operating pump.

216 investigated by using the modelling approach described in the previous section. The ship uses a two-stroke marine Diesel engine for propulsion that delivers $11,600 \mathrm{~kW}$ at its MCR point. In addition, two Diesel generator sets of $500 \mathrm{~kW}$ each are used for supplying the required ship electric energy. The characteristics of the pumps servicing the sea water and LT/HT fresh water cooling systems at their nominal operating points are presented in Table 1.

The integrated cooling system operation was simulated at various $\mathrm{M} / \mathrm{E}$ operating conditions and considering that two 
$\mathrm{D} / \mathrm{G}$ sets operate at $55 \%$ load, which can provide the maximum ship electric power demand. It must be noted that the majority of the ship operation, one $\mathrm{D} / \mathrm{G}$ set can cover the ship electric power demand, however the assumption of two operating $\mathrm{D} / \mathrm{G}$ sets was considered in order to take into account a more demanding scenario for the operation of the ship cooling system. Various scenarios were considered for the cooling system pumps including the pumps operation at fixed speed, the pumps speed control and setting two different constraints for the temperature difference at the system heat exchangers sides.

In addition, the annual required energy was estimated for each scenario based on the annual engine operating profile according to the data presented in [17] for a similar size vessel and shown in Figure 5. The annual energy is calculated by using the following equation:

$$
E_{a}=H_{a} \sum_{j=1}^{n}\left(\frac{P O T_{j}}{100} \sum_{i=1}^{k} P_{e l, i}\right)
$$

where $\mathrm{H}_{\mathrm{a}}$ denotes the annual operating hours, POT denotes the percentage of time the main engine operates at the specific load, $\mathrm{j}$ denotes the different engine load points according to the considered profile, and i denotes the operating pumps of the ship cooling system at each main engine load.

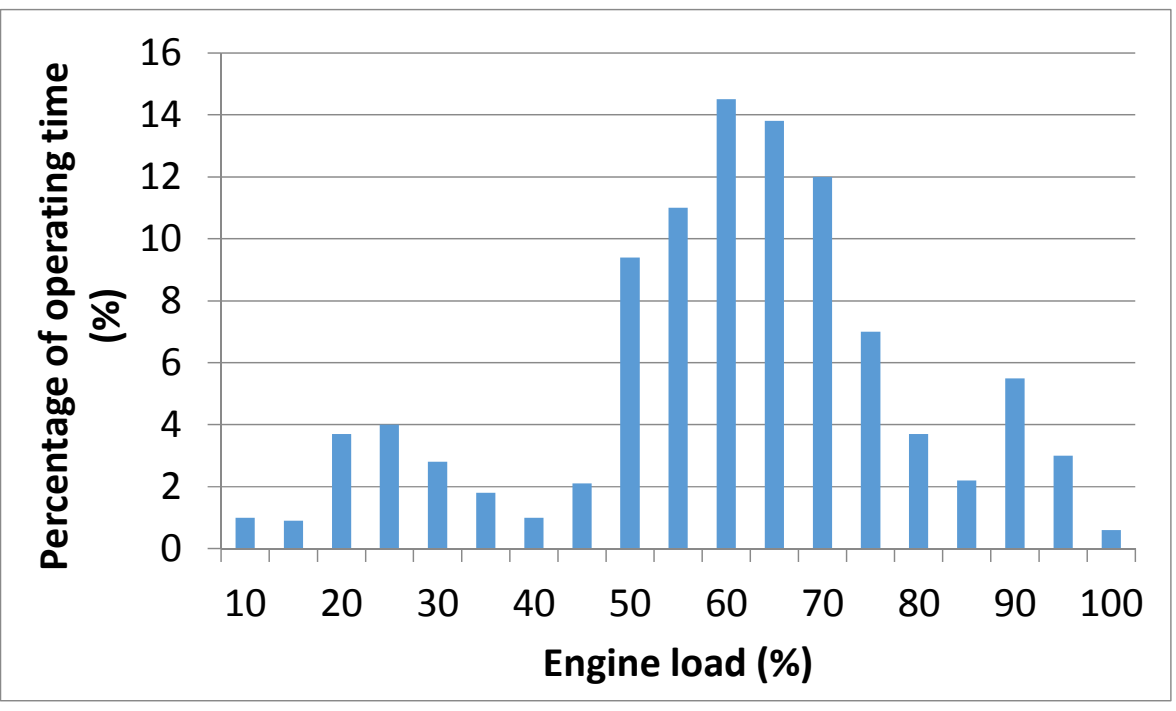

Figure 5: Ship main engine operating profile used for calculating the annual energy demand taken from [17]

The main engine and $\mathrm{D} / \mathrm{G}$ sets heat capacities were obtained by the manufactures project guides $[18,19]$. The cooling systems characteristics were estimated based on the ship piping systems drawings and the list of machinery. An amount of $4 \%$ losses for additional equipment losses (heat, cabling, etc.) was included in the calculations. In all the examined cases herein, the temperature of sea water entering the central cooler was considered to be $25^{\circ} \mathrm{C}$, whereas the set points of the LT and HT three-way valves were taken as $36^{\circ} \mathrm{C}$ and $80^{\circ} \mathrm{C}$, respectively. As the cooling system should be able to cover the main engine and ship machinery requirements under varying conditions (from arctic to tropic; from low loads 
to full load), the system is designed to withstand the extreme conditions and thus, the corresponding calculations are usually carried out at the maximum bearable (for the system) temperature of $36^{\circ} \mathrm{C}$ for the $\mathrm{LT}$ fresh water. Therefore, in the present study we used this temperature set point and calculated the system pumps power demand considering various operating cases (pump speed different than the baseline). This results in a demanding operating scenario for the cooling system as usually the sea water temperature and the set point for the LT fresh water temperature are less and therefore, greater openings of the three-way valve (in comparison with the predicted values presented below) are expected.

The LT three-way valve temperature set point may only slightly affect the main and auxiliary engines brake specific fuel consumption as it can influence the air coolers operation and up to an extent the engines scavenging air temperature. However, as it is mainly adjusted to match the prevailing environmental conditions, its contribution on the ship engines operation cannot readily identified. It must be noted that such an investigation is outside the scope of the present study. The first investigated scenario considers the pumps operation at their rated speed, i.e. at $1200 \mathrm{r} / \mathrm{min}$. The obtained results for the operation of the $\mathrm{M} / \mathrm{E}$ at four different loads (namely $25 \%, 50 \%, 75 \%$ and $100 \%$ of its $\mathrm{MCR}$ point) considering that two D/G sets operate at 55\% load in all cases are presented in Table 2. The calculations were based on the constraint that the temperature difference at the coolers sides should be greater than $5^{\circ} \mathrm{C}$ as proposed to [16]. By elaborating the results of Table 2, it can be inferred that the central cooler thermal flows (fresh water/sea water) have been in adequate convergence with difference less than $\pm 0.5 \%$ (differences lower than $\pm 1.3 \%$ were obtained for the results presented in the subsequent Tables 3-5). When the ship main engine operates at $100 \%$ load, two sea water pumps and two LT fresh water pump should operate in order to satisfy the system heat demands. However, the obtained flow rates for the each operating SW and LT fresh water pumps were lower than their nominal ones, which means that there is adequate capacity for covering additional heat removal needs from the rest auxiliary machinery. The flow rate of the HT fresh water pump is slightly lower than its nominal value as this system covers only the main engine jacket water needs. The temperature differences at the central cooler sides are $6.9^{\circ} \mathrm{C}$ and $11^{\circ} \mathrm{C}$, respectively. For the operation of M/E at lower loads, one pump of each group (i.e. seawater, LT fresh water, HT fresh water) is required to cover the system needs. All operating pumps run at flow rates slightly lower than their nominal values and therefore, the power demand is expected to be close to the rated power, which can also be inferred by comparing the data contained in Tables 1 and 2 . Another point that needs attention is the pressure level of the LT and HT fresh water entering the main and auxiliary engines. According to the main engine manufacturer, a typical range for the HT fresh water manometric pressure is between 3.5 and 4.5 bar with the alarm limit typically being set at 2 bar. The respective typical range for the engine air cooler manometric pressure is $2-4.5$ bar with the low alarm lever being set at 1 bar. By taking into account that the LT 
and HT systems expansion tanks are installed $15 \mathrm{~m}$ above the respective pumps suction pipes, the calculated manometric pressure values for the case of $100 \%$ load main engine operation were found to be 2.55 bar for the air cooler and LO cooler inlets, respectively, and 3.75 bar for the main engine HT inlet. Similar values were obtained for the other investigated cases, as the pumps operating points were very close to the operating points for the $100 \%$ main engine load case. As it was expected, the calculated pressure values lay within the recommended ranges for the pumps operation at their nominal speed of $1200 \mathrm{rpm}$ ). In addition, although the engine manufacturer proposes a recommended head value for the sea water pump, there is not any specific requirement for the sea water pressure level.

A second case was simulated considering the system pumps operation at $1100 \mathrm{r} / \mathrm{min}$, which can be obtained by using a variable speed drive. The obtained results for the operation of the $\mathrm{M} / \mathrm{E}$ at four different loads (namely $25 \%, 50 \%, 75 \%$ and $100 \%$ of their MCR points) considering the two D/G sets operate at $55 \%$ load are presented in Table 3 . For the case where the ship main engine operates at $100 \%$ load, the sea water and HT fresh water pumps can cover the system requirements; however the LT fresh water pumps need to operate at their rated speed in order to satisfy the system constraint $\left(5^{\circ} \mathrm{C}\right.$ temperature difference at heat exchangers sides). Furthermore, even though at full load the LT pumps operate at the rated speed, their power demand is higher compared to baseline case due to the losses of the variable frequency drive. However, there is a reduction in the total required power by $11.6 \mathrm{kWe}$ (113.9 instead of $125.5 \mathrm{kWe}$ ), i.e. in percentage of $9.24 \%$. When the ship main engine operates at lower loads, one pump unit from each group is adequate to cover the system needs as the total heat capacity is lower, and as a result less total power (compared to the case where the main engine operates at $100 \%$ load) is required.

For the $25 \%$ load operation of the main engine, the manometric pressure upstream the main engine LO and air coolers was calculated at 2.4 bar, whereas the a value of 3.4 bar was derived for the manometric pressure at the main engine jacket circuit inlet. It can be inferred that there is a leeway for the LT pumps to operate at a lower speed, however the HT pump marginally provides the required pressure level in the HT cooling water system.

The total required power as function of the M/E load for the two scenarios presented above is shown in Figure 6. The electric power demand reduction when the pump speed is reduced lies in the region of $9.24 \%$ for the $100 \%$ main engine load operation and $14.4 \%$ for operation of the main engine at lower loads. As it can be also seen in Figure 6, the total power demand depends on the number of the operating pumps and their speed. In both the investigated cases, the power demand is almost constant for the operation of main engine for $25 \%$ to $75 \%$ load where one pump of each group operates. Therefore, it is concluded that there is potential for reducing the system power demand by using variable speed drives and appropriate control of the cooling system pumps speed.

The system operation considering the usage of variable speed drives was simulated and the pumps speed values that 
result in the minimum power demand were calculated for the cases of setting the constraint for the minimum temperature difference at $5^{\circ} \mathrm{C}($ denoted as $\Delta \operatorname{Tmin} 1)$ and $10^{\circ} \mathrm{C}($ denoted as $\Delta \operatorname{Tmin} 2)$ at the system heat exchangers sides. The former represents a realistic operating scenario, whereas the latter represents a more demanding scenario for the system actual operation. The respective results are presented in Tables 4 and 5 and in Figure 7. For the former case (Table 4), the system pumps speed values are considerably reduced in comparison with the baseline case, and as a result the total power demand is significantly lower. For the latter case (Table 5), the power demand is higher but is still lower than the one of the baseline case for $\mathrm{M} / \mathrm{E}$ load lower than $75 \%$. For operation of the ship main engine at $100 \%$ load, the sea water pump must provide greater flow rate in order to satisfy the $10^{\circ} \mathrm{C}$ sides temperature difference constraint and therefore, greater SW pump speed is needed (1380 r/min instead of $1200 \mathrm{r} / \mathrm{min})$, which results in greater power demand. With regards to the manometric pressure constrains for the main engine operation at $25 \%$ load (the rotational speed fo LT and HT pumps were found to be 500 and $550 \mathrm{r} / \mathrm{min}$, respectively), the calculated values were 1.7 bar for the LT cooling system (upstream LO and air coolers) and 2 bar, respectively. Both values are outside the recommended ranges. In addition, the HT system alarm will be triggered at this operating pressure level. Therefore, it can be deduced that the operation of the LT and HT cooling pumps at so low rotational speed cannot be allowed, unless a change in these system design is investigated. A possible solution on this is the proposal of closed pressurised expansion tanks for each cooling system (industrial expansion tanks with volumes up to $15 \mathrm{~m}^{3}$ are available).

Finally, the estimation of the annual energy demand of the integrated cooling system is presented in Figure 8 . The annual ship operating profile was taken into account as well as the ship annual sailing hours, which were estimated by considering an average round trip distance of $9.000 \mathrm{~nm}$, a sailing speed of 12 knots and $15 \%$ maintenance time. It is inferred from the results shown in Figure 8 that there is a noteworthy potential for energy saving from the operation of the cooling system if variable speed drive technologies are used on-board ships.

Table 1 Cooling system pumps nominal characteristics

\begin{tabular}{ccc}
\hline & Speed $(\mathrm{r} / \mathrm{min})$ & 1200 \\
SW pumps & Number & 2 \\
& Rated power $(\mathrm{kWe})$ & 37 \\
& Head $(\mathrm{m})$ & 25 \\
& Flow rate $\left(\mathrm{m}^{3} / \mathrm{h}\right)$ & 400 \\
\hline & Speed $(\mathrm{r} / \mathrm{min})$ & 1200 \\
LT fresh water pumps & Number & 2 \\
& Rated power $(\mathrm{kWe})$ & 37 \\
& Head $(\mathrm{m})$ & 30 \\
& Flow rate $\left(\mathrm{m}^{3} / \mathrm{h}\right)$ & 350 \\
\hline & Speed $\left(\mathrm{r} / \mathrm{min}^{2}\right)$ & 1200 \\
HT fresh water pump & Number & 2 \\
& Rated power $(\mathrm{kWe})$ & 15 \\
& Head $(\mathrm{m})$ & 30 \\
& Flow rate $\left(\mathrm{m}^{3} / \mathrm{h}\right)$ & 97 \\
\hline
\end{tabular}


Table 2 Simulation results for the baseline case (1200 rpm)

329

\begin{tabular}{|c|c|c|c|c|c|c|c|c|c|c|c|c|c|}
\hline $\begin{array}{l}\text { Main } \\
\text { Engine } \\
\text { load } \\
(\%)\end{array}$ & $\begin{array}{l}\text { System } \\
\text { pumps }\end{array}$ & $\begin{array}{l}\text { Pump } \\
\text { speed } \\
\text { (rpm) }\end{array}$ & $\begin{array}{c}\text { No of } \\
\text { operating } \\
\text { pumps }\end{array}$ & $\begin{array}{l}\text { Total } \\
\text { electric } \\
\text { Power } \\
\text { (kW) }\end{array}$ & $\begin{array}{c}\text { LT 3-way } \\
\text { valve } \\
\text { By-pass } \\
\text { flow } \\
\text { percentage } \\
(\%)\end{array}$ & $\begin{array}{l}\text { HT 3-way } \\
\text { valve } \\
\text { By-pass } \\
\text { flow } \\
\text { percentage } \\
(\%)\end{array}$ & $\begin{array}{c}\text { total flow } \\
\text { rate } \\
\left(\mathrm{m}^{3} / \mathrm{h}\right)\end{array}$ & $\begin{array}{c}\text { Central } \\
\text { cooler } \\
\text { inlet } \\
\text { Temp. } \\
\text { FW side } \\
\left({ }^{\circ} \mathrm{C}\right)\end{array}$ & $\begin{array}{c}\text { Central } \\
\text { cooler } \\
\text { outlet } \\
\text { Temp. } \\
\text { FW side } \\
\left({ }^{\circ} \mathrm{C}\right)\end{array}$ & $\begin{array}{c}\text { Central } \\
\text { cooler } \\
\text { outlet } \\
\text { Temp. } \\
\text { SW side } \\
\left({ }^{\circ} \mathrm{C}\right)\end{array}$ & $\begin{array}{l}\text { HTFW } \\
\text { cooler } \\
\text { inlet } \\
\text { Temp. } \\
\text { LT FW } \\
\text { side } \\
\left({ }^{\circ} \mathrm{C}\right) \\
\end{array}$ & $\begin{array}{l}\text { HTFW } \\
\text { cooler } \\
\text { outlet } \\
\text { Temp. } \\
\text { LT FW } \\
\text { side } \\
\left({ }^{\circ} \mathrm{C}\right) \\
\end{array}$ & $\begin{array}{c}\text { HTFW } \\
\text { cooler } \\
\text { outlet } \\
\text { Temp. } \\
\text { HT FW } \\
\text { side } \\
\left({ }^{\circ} \mathrm{C}\right) \\
\end{array}$ \\
\hline \multirow{3}{*}{25} & SW & 1200 & 1 & 30.36 & \multirow{3}{*}{$40 \%$} & \multirow{3}{*}{$60 \%$} & 272.8 & \multirow{3}{*}{43.2} & \multirow{3}{*}{31.2} & \multirow{3}{*}{30.8} & \multirow{3}{*}{42.0} & \multirow{3}{*}{50.1} & \multirow{3}{*}{65.6} \\
\hline & LT & 1200 & 1 & 35.76 & & & 210.0 & & & & & & \\
\hline & HT & 1200 & 1 & 10.49 & & & 79.0 & & & & & & \\
\hline \multirow{3}{*}{50} & SW & 1200 & 1 & 30.33 & \multirow{3}{*}{$25 \%$} & \multirow{3}{*}{$50 \%$} & 272.8 & \multirow{3}{*}{51.2} & \multirow{3}{*}{31.0} & \multirow{3}{*}{37.5} & \multirow{3}{*}{46.0} & \multirow{3}{*}{62.3} & \multirow{3}{*}{62.0} \\
\hline & LT & 1200 & 1 & 36.00 & & & 213.7 & & & & & & \\
\hline & HT & 1200 & 1 & 11.05 & & & 85.8 & & & & & & \\
\hline \multirow{3}{*}{75} & sW & 1200 & 1 & 30.33 & \multirow{3}{*}{$20 \%$} & \multirow{3}{*}{$35 \%$} & 272.8 & \multirow{3}{*}{57.7} & \multirow{3}{*}{30.6} & \multirow{3}{*}{42.8} & \multirow{3}{*}{47.8} & \multirow{3}{*}{68.0} & \multirow{3}{*}{62.3} \\
\hline & LT & 1200 & 1 & 36.15 & & & 214.1 & & & & & & \\
\hline & HT & 1200 & 1 & 11.27 & & & 88.55 & & & & & & \\
\hline \multirow{3}{*}{100} & sW & 1200 & 2 & 52.59 & \multirow{3}{*}{$0 \%$} & \multirow{3}{*}{$0 \%$} & 338.7 & \multirow{3}{*}{55.9} & \multirow{3}{*}{36.0} & \multirow{3}{*}{49.0} & \multirow{3}{*}{44.0} & \multirow{3}{*}{59.6} & \multirow{3}{*}{64.4} \\
\hline & LT & 1200 & 2 & 61.41 & & & 390.0 & & & & & & \\
\hline & HT & 1200 & 1 & 11.51 & & & 92.7 & & & & & & \\
\hline
\end{tabular}

Table 3 Simulation results for the case where the pumps operate at 1100rpm

\begin{tabular}{|c|c|c|c|c|c|c|c|c|c|c|c|c|c|}
\hline $\begin{array}{l}\text { Main } \\
\text { Engine } \\
\text { load } \\
(\%)\end{array}$ & $\begin{array}{l}\text { System } \\
\text { pumps }\end{array}$ & $\begin{array}{l}\text { Pump } \\
\text { speed } \\
\text { (rpm) }\end{array}$ & $\begin{array}{c}\text { No of } \\
\text { operating } \\
\text { pumps }\end{array}$ & $\begin{array}{c}\text { Total } \\
\text { electric } \\
\text { Power } \\
(\mathrm{kW})\end{array}$ & $\begin{array}{l}\text { LT 3-way } \\
\text { valve } \\
\text { By-pass } \\
\text { flow } \\
\text { percentage } \\
(\%)\end{array}$ & \begin{tabular}{|c|} 
HT 3-way \\
valve \\
By-pass \\
flow \\
percentage \\
$(\%)$
\end{tabular} & $\begin{array}{c}\text { total flow } \\
\text { rate } \\
\left(\mathrm{m}^{3} / \mathrm{h}\right)\end{array}$ & $\begin{array}{c}\text { Central } \\
\text { cooler } \\
\text { inlet } \\
\text { Temp. } \\
\text { FW side } \\
\left({ }^{\circ} \mathrm{C}\right)\end{array}$ & $\begin{array}{l}\text { Central } \\
\text { cooler } \\
\text { outlet } \\
\text { Temp. } \\
\text { FW side } \\
\left({ }^{\circ} \mathrm{C}\right)\end{array}$ & $\begin{array}{c}\text { Central } \\
\text { cooler } \\
\text { outlet } \\
\text { Temp. } \\
\text { SW side } \\
\left({ }^{\circ} \mathrm{C}\right)\end{array}$ & $\begin{array}{c}\text { HTFW } \\
\text { cooler } \\
\text { inlet } \\
\text { Temp. } \\
\text { LT FW side } \\
\left({ }^{\circ} \mathrm{C}\right)\end{array}$ & $\begin{array}{l}\text { HTFW } \\
\text { cooler } \\
\text { outlet } \\
\text { Temp. } \\
\text { LT FW } \\
\text { side } \\
\left({ }^{\circ} \mathrm{C}\right)\end{array}$ & $\begin{array}{l}\text { HTFW } \\
\text { cooler } \\
\text { outlet } \\
\text { Temp. } \\
\text { HT FW } \\
\text { side } \\
\left({ }^{\circ} \mathrm{C}\right)\end{array}$ \\
\hline \multirow{3}{*}{25} & SW & 1100 & 1 & 25.80 & \multirow{3}{*}{$30 \%$} & \multirow{3}{*}{$57 \%$} & 250.0 & \multirow{3}{*}{43.8} & \multirow{3}{*}{32.6} & \multirow{3}{*}{31.4} & \multirow{3}{*}{42.8} & \multirow{3}{*}{52.6} & \multirow{3}{*}{65.4} \\
\hline & LT & 1100 & 1 & 30.40 & & & 195.5 & & & & & & \\
\hline & $\mathrm{HT}$ & 1100 & 1 & 9.35 & & & 73.6 & & & & & & \\
\hline \multirow{3}{*}{50} & SW & 1100 & 1 & 25.81 & \multirow{3}{*}{$20 \%$} & \multirow{3}{*}{$40 \%$} & 250.0 & \multirow{3}{*}{52.6} & \multirow{3}{*}{31.9} & \multirow{3}{*}{38.7} & \multirow{3}{*}{47.2} & \multirow{3}{*}{65.0} & \multirow{3}{*}{63.5} \\
\hline & LT & 1100 & 1 & 30.90 & & & 196.3 & & & & & & \\
\hline & $\mathrm{HT}$ & 1100 & 1 & 9.69 & & & 80.7 & & & & & & \\
\hline \multirow{3}{*}{75} & SW & 1100 & 1 & 25.80 & \multirow{3}{*}{$16 \%$} & \multirow{3}{*}{$32 \%$} & 250.0 & \multirow{3}{*}{59.6} & \multirow{3}{*}{31.1} & \multirow{3}{*}{44.5} & \multirow{3}{*}{48.9} & \multirow{3}{*}{71.0} & \multirow{3}{*}{61.5} \\
\hline & LT & 1100 & 1 & 31.10 & & & 196.8 & & & & & & \\
\hline & $\mathrm{HT}$ & 1100 & 1 & 10.21 & & & 81.4 & & & & & & \\
\hline \multirow{3}{*}{100} & sw & 1100 & 2 & 44.89 & \multirow{3}{*}{$0 \%$} & \multirow{3}{*}{$0 \%$} & 310.0 & \multirow{3}{*}{56.0} & \multirow{3}{*}{36.0} & \multirow{3}{*}{51.0} & \multirow{3}{*}{44.0} & \multirow{3}{*}{59.7} & \multirow{3}{*}{63.0} \\
\hline & LT & 1200 & 2 & 61.41 & & & 390.0 & & & & & & \\
\hline & $\mathrm{HT}$ & 1100 & 1 & 7.61 & & & 85.0 & & & & & & \\
\hline
\end{tabular}


Table 4 Simulation results for the case of using variable speed drives for obtaining minimum system power under the constraint of $5^{\circ} \mathrm{C}$ allowed minimum temperature difference at heat exchanger sides $(\Delta \mathrm{Tmin} 1)$

\begin{tabular}{|c|c|c|c|c|c|c|c|c|c|c|c|c|c|}
\hline $\begin{array}{l}\text { Main } \\
\text { Engine } \\
\text { load } \\
(\%)\end{array}$ & $\begin{array}{l}\text { System } \\
\text { pumps }\end{array}$ & $\begin{array}{l}\text { Pump } \\
\text { speed } \\
\text { (rpm) }\end{array}$ & $\begin{array}{l}\text { No of } \\
\text { operating } \\
\text { pumps }\end{array}$ & $\begin{array}{l}\text { Total } \\
\text { electric } \\
\text { Power } \\
(\mathrm{kW})\end{array}$ & $\begin{array}{c}\text { LT 3-way } \\
\text { valve } \\
\text { By-pass } \\
\text { flow } \\
\text { percentage } \\
(\%)\end{array}$ & $\begin{array}{c}\text { HT 3-way } \\
\text { valve } \\
\text { By-pass } \\
\text { flow } \\
\text { percentage } \\
(\%)\end{array}$ & $\begin{array}{c}\text { total flow } \\
\text { rate } \\
\left(\mathrm{m}^{3} / \mathrm{h}\right)\end{array}$ & $\begin{array}{c}\text { Central } \\
\text { cooler } \\
\text { inlet } \\
\text { Temp. } \\
\text { FW side } \\
\left({ }^{\circ} \mathrm{C}\right)\end{array}$ & $\begin{array}{l}\text { Central } \\
\text { cooler } \\
\text { outlet } \\
\text { Temp. } \\
\text { FW side } \\
\left({ }^{\circ} \mathrm{C}\right)\end{array}$ & $\begin{array}{l}\text { Central } \\
\text { cooler } \\
\text { outlet } \\
\text { Temp. } \\
\text { SW side } \\
\left({ }^{\circ} \mathrm{C}\right)\end{array}$ & \begin{tabular}{|c} 
HTFW \\
cooler \\
inlet \\
Temp. \\
T FW side \\
$\left({ }^{\circ} \mathrm{C}\right)$
\end{tabular} & $\begin{array}{l}\text { HTFW } \\
\text { cooler } \\
\text { outlet } \\
\text { Temp. } \\
\text { LT FW } \\
\text { side } \\
\left({ }^{\circ} \mathrm{C}\right)\end{array}$ & $\begin{array}{c}\text { HTFW } \\
\text { cooler } \\
\text { outlet } \\
\text { Temp. } \\
\text { HT FW } \\
\text { side } \\
\left({ }^{\circ} \mathrm{C}\right)\end{array}$ \\
\hline \multirow{3}{*}{25} & SW & 350 & 1 & 6.60 & \multirow{3}{*}{$0 \%$} & \multirow{3}{*}{$50 \%$} & 78.3 & \multirow{3}{*}{53.0} & \multirow{3}{*}{36.0} & \multirow{3}{*}{45.3} & \multirow{3}{*}{51.2} & \multirow{3}{*}{73.0} & \multirow{3}{*}{56.3} \\
\hline & LT & 500 & 1 & 9.14 & & & 89.6 & & & & & & \\
\hline & HT & 550 & 1 & 2.66 & & & 38.4 & & & & & & \\
\hline \multirow{3}{*}{50} & SW & 600 & 1 & 8.26 & \multirow{3}{*}{$0 \%$} & \multirow{3}{*}{$16 \%$} & 135.3 & \multirow{3}{*}{58.6} & \multirow{3}{*}{36.0} & \multirow{3}{*}{50.2} & \multirow{3}{*}{51.3} & \multirow{3}{*}{75.7} & \multirow{3}{*}{56.1} \\
\hline & LT & 800 & 1 & 16.20 & & & 144.0 & & & & & & \\
\hline & $\mathrm{HT}$ & 550 & 1 & 2.85 & & & 41.0 & & & & & & \\
\hline \multirow{3}{*}{75} & SW & 800 & 1 & 12.31 & \multirow{3}{*}{$0 \%$} & \multirow{3}{*}{$0 \%$} & 181.0 & \multirow{3}{*}{61.7} & \multirow{3}{*}{36.0} & \multirow{3}{*}{51.9} & \multirow{3}{*}{50.0} & \multirow{3}{*}{74.2} & \multirow{3}{*}{55.7} \\
\hline & LT & 1000 & 1 & 24.51 & & & 180.2 & & & & & & \\
\hline & HT & 550 & 1 & 2.92 & & & 42.1 & & & & & & \\
\hline \multirow{3}{*}{100} & SW & 1100 & 2 & 45.96 & \multirow{3}{*}{$0 \%$} & \multirow{3}{*}{$0 \%$} & 310.0 & \multirow{3}{*}{55.9} & \multirow{3}{*}{36.0} & \multirow{3}{*}{51.0} & \multirow{3}{*}{44.0} & \multirow{3}{*}{59.7} & \multirow{3}{*}{48.9} \\
\hline & LT & 1200 & 2 & 61.40 & & & 390.0 & & & & & & \\
\hline & HT & 600 & 1 & 3.15 & & & 46.5 & & & & & & \\
\hline
\end{tabular}

Table 5 Simulation results for the case of using variable speed drives for obtaining minimum system power under the constraint of $10^{\circ} \mathrm{C}$ allowed minimum temperature difference at heat exchanger sides $(\Delta \mathrm{Tmin} 2)$

\begin{tabular}{|c|c|c|c|c|c|c|c|c|c|c|c|c|c|}
\hline $\begin{array}{l}\text { Main } \\
\text { Engine } \\
\text { load } \\
(\%)\end{array}$ & $\begin{array}{l}\text { System } \\
\text { pumps }\end{array}$ & $\begin{array}{l}\text { Pump } \\
\text { speed } \\
\text { (rpm) }\end{array}$ & $\begin{array}{l}\text { No of } \\
\text { operating } \\
\text { pumps }\end{array}$ & $\begin{array}{l}\text { Total } \\
\text { electric } \\
\text { Power } \\
(\mathrm{kW})\end{array}$ & $\begin{array}{l}\text { LT 3-way } \\
\text { valve } \\
\text { By-pass } \\
\text { flow } \\
\text { percentage } \\
(\%)\end{array}$ & $\begin{array}{l}\text { HT 3-way } \\
\text { valve } \\
\text { By-pass } \\
\text { flow } \\
\text { percentage } \\
(\%)\end{array}$ & $\begin{array}{c}\text { total flow } \\
\text { rate } \\
\left(\mathrm{m}^{3} / \mathrm{h}\right)\end{array}$ & $\begin{array}{l}\text { Central } \\
\text { cooler } \\
\text { inlet } \\
\text { Temp. } \\
\text { FW side } \\
\left({ }^{\circ} \mathrm{C}\right)\end{array}$ & $\begin{array}{c}\text { Central } \\
\text { cooler } \\
\text { outlet } \\
\text { Temp. } \\
\text { FW side } \\
\left({ }^{\circ} \mathrm{C}\right)\end{array}$ & $\begin{array}{c}\text { Central } \\
\text { cooler } \\
\text { outlet } \\
\text { Temp. } \\
\text { SW side } \\
\left({ }^{\circ} \mathrm{C}\right)\end{array}$ & $\begin{array}{c}\text { HTFW } \\
\text { cooler } \\
\text { inlet } \\
\text { Temp. } \\
\text { T FW side } \\
\left({ }^{\circ} \mathrm{C}\right)\end{array}$ & $\begin{array}{l}\text { HTFW } \\
\text { cooler } \\
\text { outlet } \\
\text { Temp. } \\
\text { LT FW } \\
\text { side } \\
\left({ }^{\circ} \mathrm{C}\right)\end{array}$ & $\begin{array}{l}\text { HTFW } \\
\text { cooler } \\
\text { outlet } \\
\text { Temp. } \\
\text { HT FW } \\
\text { side } \\
\left({ }^{\circ} \mathrm{C}\right)\end{array}$ \\
\hline \multirow{3}{*}{25} & SW & 600 & 1 & 8.26 & \multirow{3}{*}{$0 \%$} & \multirow{3}{*}{$42 \%$} & 135.3 & \multirow{3}{*}{46.6} & \multirow{3}{*}{36.0} & \multirow{3}{*}{36.6} & \multirow{3}{*}{45.4} & \multirow{3}{*}{59.0} & \multirow{3}{*}{60.2} \\
\hline & LT & 800 & 1 & 16.20 & & & 144.0 & & & & & & \\
\hline & $\mathrm{HT}$ & 550 & 1 & 2.74 & & & 39.7 & & & & & & \\
\hline \multirow{3}{*}{50} & SW & 800 & 1 & 12.28 & \multirow{3}{*}{$0 \%$} & \multirow{3}{*}{$10 \%$} & 181.0 & \multirow{3}{*}{54.0} & \multirow{3}{*}{36.0} & \multirow{3}{*}{44.0} & \multirow{3}{*}{48.2} & \multirow{3}{*}{67.7} & \multirow{3}{*}{58.2} \\
\hline & LT & 1000 & 1 & 23.95 & & & 180.0 & & & & & & \\
\hline & $\mathrm{HT}$ & 550 & 1 & 2.74 & & & 41.5 & & & & & & \\
\hline \multirow{3}{*}{75} & sw & 1000 & 1 & 19.95 & \multirow{3}{*}{$0 \%$} & \multirow{3}{*}{$0 \%$} & 226.8 & \multirow{3}{*}{57.4} & \multirow{3}{*}{36.0} & \multirow{3}{*}{46.0} & \multirow{3}{*}{47.7} & \multirow{3}{*}{67.7} & \multirow{3}{*}{57.7} \\
\hline & LT & 1200 & 1 & 36.08 & & & 216.5 & & & & & & \\
\hline & HT & 600 & 1 & 2.74 & & & 46.0 & & & & & & \\
\hline \multirow{3}{*}{100} & SW & 1380 & 2 & 90.40 & \multirow{3}{*}{$0 \%$} & \multirow{3}{*}{$0 \%$} & 390.0 & \multirow{3}{*}{55.9} & \multirow{3}{*}{36.0} & \multirow{3}{*}{45.8} & \multirow{3}{*}{44.0} & \multirow{3}{*}{59.8} & \multirow{3}{*}{53.6} \\
\hline & LT & 1200 & 2 & 61.40 & & & 390.0 & & & & & & \\
\hline & HT & 700 & 1 & 5.00 & & & 54.7 & & & & & & \\
\hline
\end{tabular}




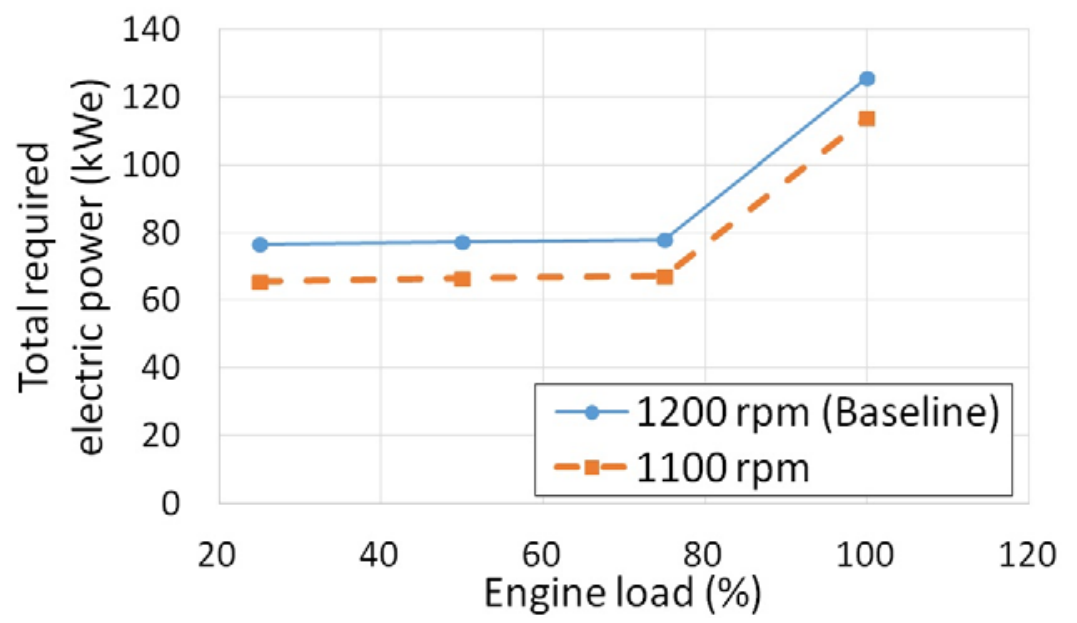

Figure 6: Cooling system total electric power demand

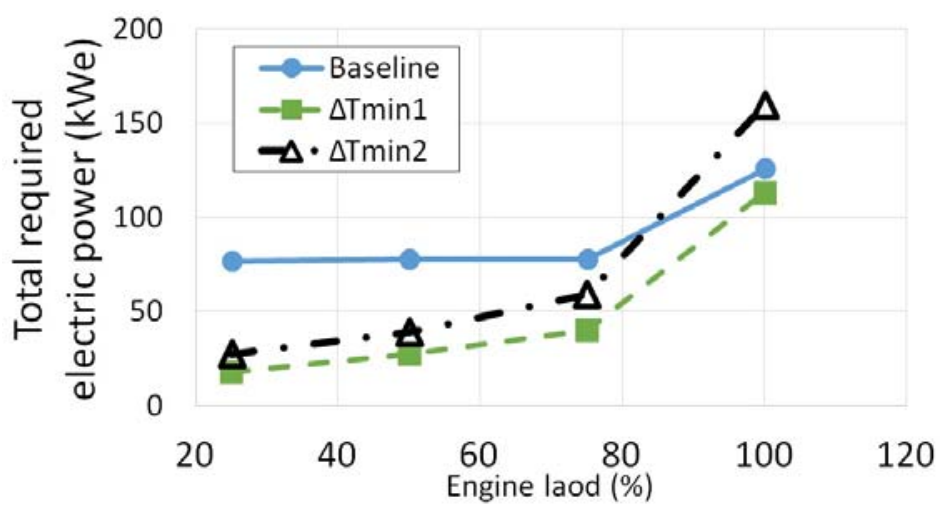

Figure 7: Cooling system total minimum electric power demand for two different constraints of coolers sides minimum allowed temperature difference. $\Delta \operatorname{Tmin} 1: 5^{\circ} \mathrm{C} \min ; \Delta \operatorname{Tmin} 2: 10^{\circ} \mathrm{C}$.

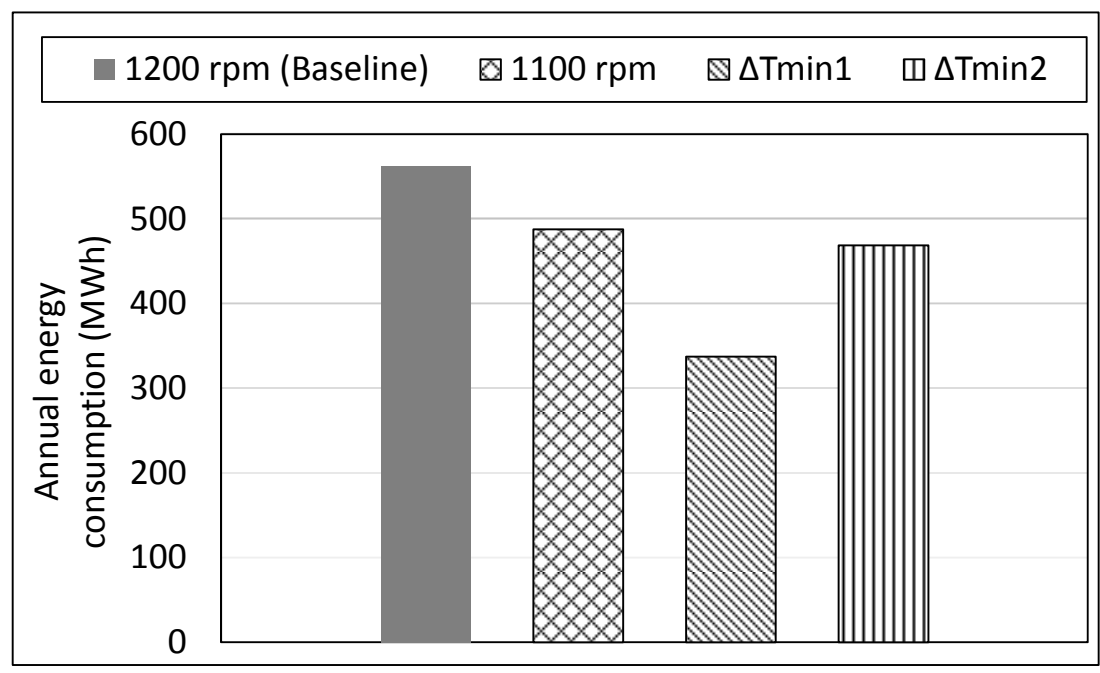

Figure 8: Annual energy consumption 


\section{Conclusions}

The operation of the integrated sea water/ fresh water cooling system of a handymax bulk carrier was investigated through simulation. Various cases of operating the system pumps including constant and variable speed were examined. The main conclusions derived from this work are summarised as follows.

- When the pumps operate at their rated speed the power demand is close to the rated pumps power independently of the cooling system rejected heat capacity that vary with the $\mathrm{M} / \mathrm{E}$ and $\mathrm{D} / \mathrm{G}$ sets loading.

- $\quad$ By reducing the pump speed the required pump power can lower, thus enabling the fuel saving.

- Variable frequency drives and control of the cooling system pumps speed can result in substantial reduction of the required power considering that the ship engines and machinery rarely operate at their maximum load.

- There is high potential for reduction of the required power demand with the use of variable speed drives installed in the ship cooling pumps, since the system is designed to cover the worse operating conditions i.e. tropical conditions and maximum load of ship engines and machinery, which does not represent the actual system operation.

- For the LT and HT fress water cooling pumps, their minimum rotational speeds are constrained by the engine manufacturer required pressure levels. For fully exploiting the energy saving capabilities in these systems, alternative designs including closed expension tanks need to be further investigated.

The presented simulation tool and the estimation of the annual energy consumption could be used as tool for evaluating the energy saving potential for the ship auxiliary systems and the techno-economic study of the installation of variable frequency drives for the ship main pumps and fans.

\section{Acknowledgements}

The authors gratefully acknowledge the financial support of the European Commission through the research project JOULES (www.joules-project.eu), which is jointly funded by the $7^{\text {th }}$ Framework Programme and the industry, for the 
1. IMO. (2011). Resolution MEPC.203(62), Amendments to the annex of the protocol of 1997 to amend the international convention for the prevention of pollution from ships, 1973, as modified by the protocol of 1978 relating thereto (Inclusion of regulations on energy efficiency for ships in MARPOL Annex VI), MEPC 62/24/Add.1, London: International Maritime Organization.

2. $\quad$ ABB. (2013). SW Cooling Pumps Variable Speed Drives Upgrade. ABB Technical Report.

3. Su C.L., Chung W.L., Yu K.T. (2013b). An energy-savings evaluation method for variable-frequency-drive applications on ship central cooling systems. IEEE Transactions on Industry Applications, . 50(2), 1286-1294.

4. ABB. (2012). Using Variable Frequency Drives (VFD) to save energy and reduce emissions in new builds and existing ships. ABB Technical Report.

5. Mrakovcic T., Medica V., Skific N. (2004). Numerical modelling of an engine cooling system, Journal of Mechanical Engineering, $50(2), 104-114$

6. Hansen M., Stoustrup J., Bendtsen J. (2013). Modeling and control of a single-phase marine cooling system. Control Engineering Practice, 21, 1726-1734.

7. DNV GL SE, (2015). Rules for Classification and Construction, I-1.2, July 2015, Hamburg, Germany.

8. Haaland S.E. (1983). Simple and Explicit Formulas for the Friction Factor in Turbulent Flow. Journal of Fluids Engineering, $103(5), \quad 89-90$.

9. Brkic D. (2011). Review of explicit approximations to the Colebrook relation for flow friction, Journal of Petroleum Science and Engineering, 77, 34-48.

10. Peters M.S., Timmerhais K., West R.E. (2003). Plant Design and Economics for Chemical Engineers, $5^{\text {th }}$ ed. McGraw Hill.

11. Shah R.K., Sekulic D.P., (2003). Fundamentals of heat exchanger design, John Wiley \& Sons. Technical Report.

14. Athanasiadis N. (1989). Hydrodynamic Machinery. NTUA, Athens.

15. Lobanoff V.S., Ross R.R. (1985). Centrifugal Pumps Design and Application. Gulf Publishing, Houston TX.

16. SNAME. (1990), Marine Diesel Power Plant Practises. T\&R Bulleting, No. 3-39..

17. Baldi F., Bengtsson S., Andersson A. (2013). The influence of propulsion system design on the carbon footprint of different marine fuels. Low Carbon Shipping Conference, London. 
$413 \quad$ Nomenclature

414 Symbols

415 a,b,c constants (-)

416 A pipe cross-section area $\left(\mathrm{m}^{2}\right)$

$417 \quad c_{p} \quad$ specific heat at constant pressure $(\mathrm{J} / \mathrm{kg} \mathrm{K})$

418 D pipe hydraulic diameter $(\mathrm{m})$

419 e/D relative roughness (-)

420 E energy $(\mathrm{kWh})$

421 f friction factor (-)

$422 \mathrm{~g} \quad$ gravitational acceleration $\left(\mathrm{m} / \mathrm{s}^{2}\right)$

$423 \mathrm{~h} \quad \operatorname{head}(\mathrm{m})$

$424 \mathrm{H} \quad$ operating hours (h)

$425 \quad \mathrm{~K} \quad$ loss coefficient (-)

426 L pipe length (m)

$427 \mathrm{~N} \quad$ rotational speed ( $\mathrm{r} / \mathrm{min})$

428 P power (W)

429 POT percentage of time (\%)

$430 \quad \dot{Q} \quad$ transferred heat rate $(\mathrm{W})$

431 Re Reynolds number (-)

$432 \mathrm{~T}$ temperature $(\mathrm{K})$

$433 \dot{V} \quad$ volumetric flow rate $\left(\mathrm{m}^{3} / \mathrm{s}\right)$

$434 \quad \mathrm{z} \quad$ elevation (m)

435

436 Greek symbols

$437 \Delta \quad$ difference

$438 \quad \eta \quad$ efficiency (-)

$439 \rho \quad$ fluid density $\left(\mathrm{kg} / \mathrm{m}^{3}\right)$

440

441 Subscripts

442 C cold side

443 CC central cooler

444 d drive

445 hot hot side

446 HE heat exchanger

447 HTFW high temperature fresh water

448 in inlet

449 JW jacket water 


$\begin{array}{lll}450 & \text { LT } & \text { low temperature } \\ 451 & \mathrm{~m} & \text { motor } \\ 452 & \mathrm{ME} & \text { main engine } \\ 453 & \text { o } & \text { outlet } \\ 454 & \mathrm{p} & \text { pump (-) } \\ 455 & & \\ 456 & \text { Abbreviations } \\ 457 & \text { D/E } & \text { Diesel Engine } \\ 458 & \text { D/G } & \text { Diesel Generator } \\ 459 & \text { FW } & \text { Fresh Water } \\ 460 & \text { HT } & \text { High Temperature } \\ 461 & \text { JW } & \text { Jacket Water } \\ 462 & \text { LT } & \text { Low Temperature } \\ 463 & \text { MCR } & \text { maximum continuous rating } \\ 464 & \text { M/E } & \text { Main Engine } \\ 465 & \text { SW } & \text { Sea Water } \\ 466 & \text { VFD } & \text { Variable Frequency Drive }\end{array}$

